\title{
TAFSIR HUKUM KLAUSUL "TANPA HAK" DALAM PASAL 2 UNDANG- UNDANG DARURAT NO. 12 TAHUN 1951 TENTANG MENGUBAH "ORDONNANTIE TIJDELIJKE BIJZONDERE STRAFBEPALINGEN" (STBL. 1948 NOMOR 17) DAN UNDANG-UNDANG REPUBLIK INDONESIA DAHULU NOMOR 8 TAHUN 1948
}

\author{
Agung Hartawan \\ Fakultas Hukum Universitas Brawijaya \\ MT. Haryono No.169, Ketawanggede, Kec. Lowokwaru, Kota Malang, Jawa \\ Timur 65145, \\ Email : gunghart789@gmail.com
}

\begin{abstract}
Article 2 of the Emergency Law Number 12 of 1951 there is a problem of legal obscurity. The problem is contained in article 2 specifically in the clause "without rights". The "without rights" clause has an element of legal obscurity.This paper aims to find out, understand and analyze the "no rights" clause of the use of sharp weapons stipulated in Emergency Law No. 12 of 1951. To answer the problems in this paper, the author uses normative legal research using the method of approach to legislation. The results of research in the right "use of sharp weapons regulated in the Act. So that the interpretation given in this journal for the "no rights" clause that can be threatened with criminality is the use without any interest. The purpose of having the right of interest in the use of sharp weapons regulated in the law is the use of sharp weapons as the legitimacy of a job, agriculture and heirlooms. The use of sharp weapons outside of these interests will be threatened with criminality.
\end{abstract}

Key words : Without Rights, Sharp Weapons

\begin{abstract}
ABSTRAK
Pasal 2 Undang-Undang Darurat Nomor 12 tahun 1951 terdapat permasalahan kekaburan hukum. Permasalahan tersebut terdapat pada pasal 2 khusus pada klausul kata "tanpa hak". Klausul "tanpa hak" memiliki unsur kekaburan hukum. Tulisan ini bertujuan untuk mengetahui, memahami dan menganalisis klausul "tanpa hak" penggunaan senjata tajam yang diatur dalam UU Darurat No. 12 Tahun 1951. Untuk menjawab permasalahan dalam tulisan ini , penulis menggunakan penelitian hukum normatif dengan menggunakan metode pendekatan peraturan perundang-undangan. Hasil penelitian dalam hak" penggunaan senjata tajam yang diatur dalam UU. Sehingga tafsir yang diberikan pada jurnal ini atas klausul "tanpa hak" yang dapat diancam pidana adalah penggunaan tanpa ada kepentingan. Adapun maksud yang memiliki hak kepentingan penggunaan senjata tajam yang diatur dalam UU seperti penggunaan senjata tajam sebagai sahnya suatu pekerjaan, pertanian dan benda pusaka. Penggunaan senjata tajam diluar kepentingan tersebut akan terancam pidana.
\end{abstract}

Kata Kunci : Tanpa Hak, Senjata Tajam, Undang-Undang Darurat Nomor 12 Tahun 1951

\section{PENDAHULUAN}

Negara adalah suatu wadah yang memiliki struktur organisasi sebagai pemimpin untuk melayani kepentingan bangsa.. H.J. Laski, juga mengatakan bahwa negara adalah suatu masyarakat yang diintegrasikan karena mempunyai wewenang yang bersifat memaksa dan secara sah lebih agung dari 
pada individu atau kelompok yang merupakan bagian dari masyarakat itu. Masyarakat merupakan negara yang harus ditaati baik oleh individu maupun oleh asosiasi-asosiasi, ditentukan oleh suatu wewenang yang bersifat memaksa dan mengikat. ${ }^{1}$

Pengertian negara di atas memiliki unsur memaksa yang dimiliki negara. Namun memaksa disini adalah wewenang sah untuk mengatur masyarakatnya tanpa bertindak sebagai otoriter. Wewenang yang dimiliki dilakukan dengan instrumen yang menjadi media penyalur tersebut yang kemudian sangat identik dengan negara hukum. Mac Iver menegaskan bahwa negara hukum menyelenggarakan penertiban hukum di dalam suatu masyarakat dalam suatu wilayah yang berdasarkan pada sistem hukum yang diselenggarakan oleh suatu pemerintah dengan maksud memberikan kekuasaan memaksa $^{2}$. Artinya walaupun negara memiliki wewenang memaksa namun bukan berarti negara bergerak secara otoriter. Negara melakukan wewenang memaksa sebagai pengeluaran aturan untuk menciptakan ketertiban, kemakmuran dan keamanaan terhadap ancaman yang dapat merugikan warga negara tersebut.
Seperti halnya Indonesia yang merupakan negara dengan penyelenggaraan berdasarkan instrumen hukum. Legalitas Indonesia dalam menjalankan pemerintahnya harus berdasarkan hukum terdapat dalam Pasal 1 ayat 3 Undang-Undang Dasar Negara Republik Indonesia Tahun 1945 yang menyebutkan bahwa Indonesia adalah negara hukum. Artinya negara Indonesia tidak boleh melaksanakan kewenangan tanpa ada dasar hukum yang menjadi pijakan.

Fredrich Julius Stahl salah satu pelopor negara hukum memberikan tujuan dari negara hukum itu sendiri. Menurut Stahl negara hukum memiliki tujuan untuk mewujudkan berjalannya hak asasi manusia, kebebasan setiap warga demi kesejahteraan kehidupan bersama $^{3}$. Kemudian pendapat dari Stahl diperkuat oleh pendapat Nicolo Machiavelly yang memberikan pandangan terkait tujuan negara hukum adalah menerapkan instrumen hukum untuk mewujudkan ketertiban, keamanan, dan ketentraman ${ }^{4}$. Kusnanto Anggoro dalam seminar Makalah Pembanding Hukum Nasional VIII di Denpasar Bali menyebutkan upaya yang perlu untuk mewujudkan tujuan negara di atas yaitu melakukan delegasi kewenangan pada instansi-institusi tertentu yang akan bertindak sebagai pelaku utama untuk melindungi

\footnotetext{
Kusnadi \& Saragi Bintang, (1985), Ilmu Negara, Jakarta; Perintis Press, 1985, hlm. 48. Mac Iver, (1984), Negara Hukum, Jakarta: Aksara Baru, 1984, hlm. 28.

Gautama Sudargo, (1973) Pengertian Negara Hukum, Bandung; Alumni, hlm. 8.

Nicolo Machiavelly dalam Soehino, (2004), Ilmu Negara, Jakarta; Ilmu Negara Cet 1, hlm. 52.
} 
keamanan nasional, baik ketika keamanan itu ditempatkan dalam kerangka keamanan negara maupun ketertiban umum ${ }^{5}$.

Dalam mewujudkan suatu tujuan di atas maka salah satunya negara Indonesia mengeluarkan kebijakan kriminal. Barda Nawawi Arief dalam bukunya menyebutkan pengertian kebijakan kriminal secara luas yaitu upaya untuk menjalankan instrument hukum melalui badan-badan resmi yang diberi wewenang untuk menegakkan normanorma sentral dari masyarakat ${ }^{6}$. Kemudian Barda Nawawi Arief di dalam bukunya yang lain menyebutkan kebijakan kriminal adalah perlindungan masyarakat untuk mencapai tujuan utama yang sering di masyarakat/penduduk (happiness of citizens), kehidupan kultural yang sehat dan menyegarkan (a wholesome and cultural living), kesejahteraan masyarakat (social welfare), atau untuk mencapai keseimbangan (equality) ${ }^{7}$.

Atas pendapat di atas tentu secara dogmatik dapat dikorelasikan dengan kebijakan kriminal di Indonesia. Secara yuridis negara telah mengeluarkan instrument-instrumen hukum pidana sebagai dasar hukum materil. Kemudian negara juga memiliki aparat penegak hukum (Kepolisian, Kejaksaan, dan Kehakiminan serta lembaga lainnya) sebagai pihak yang menjalankan aturan materil dalam rangka menanggulangi kejahatan guna mewujudkan kehidupan kultural yang sehat dan menyegarkan ( $a$ wholesome and cultural living), kesejahteraan masyarakat (social welfare), atau untuk mencapai keseimbangan (equality) di masyarakat Indonesia.

Kebijakan pidana merupakan sebuah produk undang-undang yang mengatur perbuatan pidana untuk diancam dengan hukum. Produk kebijakan pidana dapat dilihat atas keluarnya undang-undang nomor 1 tahun 1946 tentang Kitab Undang-Undang Hukum Pidana atau yang dikenal dengan KUHP. Mengutip pendapat Mezger yang menyebutkan pengertian hukum pidana yaitu aturan-aturan hukum yang mengikatkan pada suatu perbuatan tertentu yang memenuhi syarat-syarat tertentu suatu akibat yang berupa pidana ${ }^{8}$ Kemudian Pompe merumuskan hukum pidana sebagai semua aturan hukum yang menentukan terhadap tindakan apa yang seharusnya dijatuhkan pidana dan apa macam pidananya yang bersesuainya ${ }^{9}$.

\footnotetext{
5 Kusnanto Anggoro dalam makalah “Keamanan, Pertahanan Negara, Dan Ketertiban Umum”, disampaikan pada Seminar Pembangunan Hukum Nasional VIII Oleh Badan Pembinaan Hukum Nasional, Departemen Kehakiman dan HAM RI, Denpasar Bali Tahun 2003.

6 Arief, Barda Nawawi, (2017), Bunga Rampai Kebijakan Hukum Pidana Cet. Ke-7, Kencana; Jakarta, hlm. 3

7 Muladi \& Arief, Barda Nawawi, (2010), Teori-Teori dan Kebijakan Hukum Pidana, Bandung; Alumni, hlm. 158.

8 Ida Bagus Surya Dharma Jaya, (2015), Hukum Pidana Materil \&Formil: Pengantar Hukum Pidana, Jakarta; USAID-The Asian Foundation-Kemitraan Partnership, hlm. 2.

9 Sianturi, (1986), Asas-Asas Hukum Pidana dan Penerapannya, Jakarta; Alumni, hlm. 13.
} 
Pendapat tentang hukum pidana di atas jika dikorelasikan dengan kebijakan pidana atas KUHP yang berlaku di Indonesia memiliki makna dan tujuan. KUHP di Indonesia dikeluarkan atas dasar wewenang negara yang sah sebagai negara hukum untuk mengatur perbuatan-perbuatan tertentu yang memiliki akibat pidana dengan ancaman hukum.

Namun dalam perjalanannya, KUHP yang berlaku di Indonesia tidak dapat menjangkau perbuatan-perbuatan pidana yang baru akibat perubahan era dan zaman. Karena tidak dapat menjangkau, maka negara melalui dewan legislatif DPR Indonesia mengeluarkan undang-undang yang mengatur perbuatan pidana terpisah dari KUHP. Salah satunya telah dikeluarkannya Undang-Undang Darurat No. 12 Tahun 1951 tentang mengubah "ordonnantietijdelijke bïzondere strafbepalingen" (stbl. 1948 nomor 17) dan undang-undang Republik Indonesia Dahulu Nomor 8 Tahun 1948 dimana aturan tersebut memuat larangan penggunaan senjata api maupun senjata tajam yang dapat digunakan sebagai pemukul, penikam maupun penusuk.

Adapun legalitas larangan penggunaan senjata yang dilarang dalam penjelasan di atas akan disebutkan di bawah ini:

Pasal 1 :

(1) "Barang siapa, yang tanpa hak memasukkan ke Indonesia membuat, menerima, mencoba memperoleh, menyerahkan atau mencoba menyerahkan, menguasai, membawa, mempunyai persediaan padanya atau mempunyai dalam miliknya, menyimpan, mengangkut, menyembunyikan, mempergunakan, atau mengeluarkan dari Indonesia sesuatu senjata api, amunisi atau sesuatu bahan peledak, dihukum dengan hukuman matiatau hukuman penjara seumur hidup atau hukuman penjara sementara setinggitingginyadua puluh tahun".

Pasal 2 :

(1) "Barang siapa yang tanpa hak memasukkan ke Indonesia, membuat, menerima, mencoba memperolehnya, menyerahkan atau mencoba menyerahkan, menguasai, membawa, mempunyai persediaan padanya atau mempunyai dalam miliknya, menyimpan, mengangkut, menyembunyikan, mempergunakan atau mengeluarkan dari Indonesia sesuatu senjata pemukul, senjata penikam, atau senjata penusuk (slag-, steek-, of stootwapen), dihukum dengan hukuman penjara setinggi-tingginya sepuluh tahun".

(2) "Dalam pengertian senjata pemukul, senjata penikam atau senjata penusuk dalam pasal ini, tidak termasuk barang-barang yang nyata-nyata dimaksudkan untuk dipergunakan guna pertanian, atau untuk pekerjaanpekerjaan rumah tangga atau untuk kepentingan melakukan dengan syah pekerjaan atau yang nyata-nyata mempunyai tujuan sebagai barang pusaka atau barang kuno atau barang ajaib (merkwaardigheid)."

Dasar hukum di atas adalah beberapa penggalan pasal terkait larangan penggunaan senjata api serta senjata penikam, penusuk atau pemukul di Indonesia. Jika pasal itu dilanggar maka akan ada ancaman pidana penjara paling lama 10 (sepuluh) tahun. Aturan tersebut memiliki makna dan tujuan dalam kebijakan kriminal di Indonesia. 
Tujuannya adalah untuk menghindari dampak buruk ancaman keamanan dan ketertiban bahkan dapat digunakan sebagai tindak pidana di Indonesia. Dengan diatur dalam aturan diharapkan meminilasir penggunaan senjata api dan tajam di masyarakat agar tidak mengakibatkan gaduh, tetap terjaganya ketertiban dan mengurangi terjadinya perbuatan pidana.

Namun dalam subtansi pada aturan di atas terdapat suatu masalah. Permasalahan yang terjadi dalam aturan tersebut dapat mengganggu berjalannya aturan serta penegakan hukum di masyarakat. Permasalahan yang pertama adalah bahwa aturan tersebut sudah terlalu lama sejak tahun 1951 dikeluarkan dan belum ada perubahan hingga pada tahun 2019.

Pada regulasi yang disebutkan di atas terdapat permasalahan kekaburan hukum. Permasalahan tersebut terdapat pada pasal 1 ayat (1) \& 2 ayat (1) khusus pada klausul kata "tanpa hak". Klausul "tanpa hak" memiliki unsur kekaburan hukum. Tidak ada penjelasan lebih spesifik pada pasal 2 ayat (1) bahwa klausul "tanpa hak" itu memiliki maksud seperti apa. Atas masalah kekaburan hukum di atas dapat berpotensi terjadinya multi tafsir bagi para pihak. Kemudian secara praktikal akan terjadi permasalahan di ranah penegak hukum khususnya para penyidik kepolisian sebagai garda terdepan gerbang penafsiran tindak pidana. Penyidik kepolisian tentu memiliki kapasitas kemampuan yang berbeda. Karena terjadinya perbedaan maka tafsir atas unsur "tanpa hak" tentu memiliki perbedaan pandangan antar para penyidik yang kemudian dapat juga berimplikasi atas seseorang yang kemudian menggunakan alat yang dilarang tersebut karena pekerjaannya seperti bertani, berkebun dan aktivitas di luar lainnya yang menggunakan alat yang tajam dapat dipidana karena dianggap tanpa hak menggunakan alat tersebut.

Atas permasalan kekaburan hukum ini, perlu dilakukan sebuah tafsir yang jelas memiliki kepastian hukum dalam pemaknaannya. Tujuannya agar tidak terjadinya multitafsir atas pasal 2 undangundang darurat sebagai pembaharuan hukum pidana atas kebijakan kriminal yang dapat berjalan dalam penanggulangan kejahatan dibidang penggunaan senjata tajam dan tidak merugikan masyarakat akibat tafsir kata yang bercabang yang dapat menjerat masyarakat.

Penelitian dalam jurnal ini merupakan penelitian yuridis normatif ${ }^{10}$ yang dilakukan melalui penelitian kepustakaan. Penelusuran bahan hukum dalam penelitian ini terdiri dari bahan hukum primer dan bahan hukum sekunder. Pendekatan penelitian ini akan dilakukan melalui pendekatan terhadap salah

10 Penulisan jurnal ini dilakukan berdasarkan penelitian asas-asas hukum yang menurut Soerjono Soekanto adalah salah satu bagian dari penelitian hukum normatif, Pengantar Penelitian Hukum, Cet. 3, (Jakarta: UI Press, 2007), hlm. 51. 
satu peraturan perundangan-undangan (statute approach) di Indonesia terkhususnya meneliti salah satu Pasal UU darurat yang menjadi objek kajian jurnal ini.

\section{PEMBAHASAN}

Penafsiran Yuridis Unsur Tanpa Hak Dalam Pasal 2 Undang-Undang Darurat Nomor 12 Tahun 1951 Dalam Perspektif Kepastian Dalam Penyelenggaran Negara Hukum.

Penanggulangan kejahatan dengan menggunakan senjata tajam dilakukan oleh pemerintah dengan mengeluarkan UndangUndang Darurat Nomor 12 Tahun 1951 sebagai usaha preventif untuk mencegah atau mengurangi penggunaan senjata tajam dalam suatu kejahatan. Undang-undang Darurat No.12 tahun 1951 ini selain mengatur senjata api dan bahan peledak juga didalamnya mengatur masalah senjata tajam. Undangundang Darurat Nomor 12 tahun 1951 merupakan suatu dasar regulasi yang mengatur penggunaan senjata tajam yang dilarang.

Pembentukan aturan ini memberikan amanat terkait dengan ancaman pidana terhadap penyalahgunaan senjata tajam. Adanya pengaturan tersebut tentu dalam kriminologi hukum dikenal dengan istilah kriminalisasi. Secara umum kriminalisasi dapat diartikan suatu perbuatan yang dilakukan untuk membuat suatu perbuatan yang awalnya tidak masalah jika dilakukan, menjadi tidak boleh untuk dilakukan dan diancam pidana jika melanggarnya. UU darurat ini umurnya tergolong tua karena dibentuk pada saat Indonesia baru saja merdeka.

Sampai saat ini UU darurat ini belum juga direvisi atau diganti. Terdapat berbagai isu atas berlakunya UU darurat ini terkait kekaburan hukum dalam aturan sebagai penjeratan pemidanaan terhadap penggunaan senjata tajam yang menjadi objek dalam pengaturan dalam Undang-undang Darurat ini. Atas isu kekaburan hukum ini sangat wajib untuk dilakukan tafsir dari salah satu unsur pasal agar mendapatkan suatu makna kata yang memiliki maksud tunggal agar tidak terjadi multitafsir. Penafsiran yang sangat jelas atas unsur pasal tersebut sangat penting dikarenakan bahwa Indonesia adalah negara hukum dan penyelenggaraannya harus berdasarkan hukum yang tepat tanpa perbedaan pandangan antar pihak-pihak baik dari para penegak hukum dan masyarakat.

Indonesia yang merupakan negara hukum wajib untuk memberikan jaminan keberlakuan hukum yang adil dalam suatu aturan maupun kebijakan. Legalitas Indonesia sebagai negara hukum terdapat pada pasal 1 ayat (3) Undang-Undang Dasar Negara Republik Indonesia Tahun 1945 yang menyebutkan "Indonesia adalah negara hukum. Atas dasar legalitas tersebut tentu harus pada tatanan komitmen yang telah dibangun dalam amanat UUD agar Indonesia 
tetap konsisten untuk melaksanakan negara berdasarkan aturan hukum yang berlaku.

Keadilan biasanya dihubungkan dengan kepentingan individu para pencari keadilan, dan itu berarti keadilan menurut hukum sering diartikan dengan sebuah kemenangan dan kekalahan oleh pencari keadilan. Penting kiranya untuk memberikan pemahaman bahwa sebuah keadilan itu bersifat abstrak, tergantung dari sisi mana kita memandangnya. Oleh karena itu dalam rangka memaksimalkan tujuan hukum maka tidak hanya memenuhi rasa kepastian hukum tetapi juga memenuhi rasa keadilan.

Beberapa konsep serta teori negara hukum sebagai dasar pemikiran. Banyak sekali pemikiran-pemikiran yang dalam pandangan sebagai ukuran negara hukum yang wajib dilakukan. Salah satunya adalah supremasi hukum. Supremasi hukum adalah dasar yang paling fundamental pada suatu pondasi awal untuk melaksanakan penyelenggaraan negara yang berdasarkan hukum. Mengutip pendapat Fredish Julius Stahl yang berpendapat tentang unsur-unsur negara hukum (rechstaat) salah satunya adalah pemerintahan berdasarkan undang-undang ${ }^{11}$. Artinya dasar pemerintahan yang mentaati suatu undangundang yang berlaku sebagai pedoman. Selain itu Albert Van Dicey juga menyatakan unsur-unsur dari negara hukum yang salah satunya adalah supremacy of law ${ }^{12}$. Pendapat Dicey ini memperkuat pandangan penulis di awal atas suatu penyelenggaraan negara yang harus pada prosedur hukum yang berlaku dengan tujuan menciptakan kepatuhan pemerintah dan masyarakat sehingga ketertiban dapat dinikmati bersama-sama. Tanpa berpedoman atas peraturan yang berlaku negara berpotensi menjadi suatu pemerintahan yang otoriter dengan mementingkan kekuasaan belaka.

Penghindaran potensi kekuasaan yang otoriter atas berlakunya negara hukum dilanjutkan dengan pandangan Muhammad Yakin. Beliau berpendapat ${ }^{13}$ :

"polisi atau negara militer, tempat polisi dan prajurit memegang pemerintah dan keadilan, bukanlah pula negara Republik Indonesia ialah negara hukum (rechtsstaat, government of law) tempat keadilan yang tertulis berlaku, bukanlah negara kekuasaan (machtsstaat) tempat tenaga senjata dan kekuatan badan melakukan sewenangwenang."

Pendapat di atas menyatakan urgensi penyelanggaran berdasarkan hukum agar tetap berjalan tentu ada perangkat hukum untuk menjalankan amanat aturan serta penegak keadilan. Perangkat hukum yang terdiri berbagai aparat hukum bertindak atas

\footnotetext{
11 Sulistiyono Adi, (2007), Negara Hukum: Kekuasaan, Konsep dan Paradigma Moral, Cet. 1., LPP \& UPT , Surakarta; UNS Press, hlm. 32.

12 Koentjoro, Diana Halim, (2004), Hukum Administrasi Negara, Bogor; Ghalia, hlm.

13 Yamin Muhammad, (1982), Proklamasi dan Konstitusi Republik Indonesia, Bogor; $\overline{\text { Ghalia, }}$ hlm. 72.
} 
aturan. Tanpa ada aturan aparat penegak hukum berpotensi melakukan kesewangwenangan dengan menggunakan senjata dan kekuatannya dalam rangka memperoleh kekuasaan yang mutlak pada suatu negara.

Selain itu pendapat di atas menunjukan suatu ukuran yang harus diperhatikan dalam keberlakuan aturan pada negara hukum dalam menjamin keadilan bagi masyarakat. Aturan hukum sebagai instrumen untuk membuat suatu kebijakan yang adil dituangkan dalam aturan yang tertulis. Artinya aturan tertulis yang dibuat adalah pedoman untuk menciptakan keadilan. Tanpa pedoman atas aturan yang tertulis tersebut maka kebijakan menjadi menyimpang dan berpotensi menciptakan ketidak adilan pada masyarakat.

Aturan yang tertulis sangat identik dengan penegakan hukum yang memiliki unsur kepastian hukum. Perspektif secara umum subtansi kepastian pada suatu aturan harus pada dasar isi aturan yang dituju atau dengan kata lain dikenal dengan positivisme hukum. Hal ini sesuai dengan pandangan aliran legisme yang dipelopori Immanuel Kant. Bahwa Kant menyatakan hukum itu ada dalam aturan undang-undang. Diluar undang-undang bukanlah hukum ${ }^{14}$. Sehingga dalam hukum positif tidak ada lagi pengaruh lain diluar undang-undang baik hukum alam, hukum Tuhan maupun hukum lain, semuanya adalah hukum yang dibuat manusia. Aturan tersebut dituangkankan dalam tulisan.

Supremasi hukum yang menjadi salah satu unsur negara hukum terkhususnya bagi Indonesia berdasarkan suatu kedaulatan rakyat yang dituangkan dalam undangundang. Hal ini memiliki makna bahwa pelaksanaan undang-undang merupakan suatu kedaulatan rakyat. Sehingga suatu aturan yang berlaku dari undang-undang sifatnya tertulis. Sehingga dalam menjalankan pemerintahan yang bukan atas dasar hukum, maka tentu negara tidak menjalankan kedaulatan rakyat.

Kembali ke kepastian hukum yang sangat penting dalam penerapan suatu aturan agar tepat tanpa terjadi multi tafsir di lapangan, Kepastian hukum sebagai salah satu tujuan hukum dapat dikatakan sebagai bagian dari upaya mewujudkan keadilan dan mencegah multitafsir dalam menentutkan tindakan mana yang dilarang mana yang tidak. Bentuk nyata dari kepastian hukum ialah pelaksanaan atau penegakan hukum terhadap suatu tindakan tanpa memandang siapa yang melakukan. Kepastian diperlukan untuk mewujudkan prinsip persamaan dihadapan hukum tanpa diskriminasi.

Kepastian hukum adalah jaminan bahwa hukum dijalankan yang berhak menurut hukum dapat memperoleh haknya dan

14 Kaarlo Tauri, (1988), Critical Legal Positivism, Burlington; Ashgate, hlm. 6. 
bahwa putusan dapat dilaksanakan. Kepastian hukum merupakan perlindungan yustisiabel terhadap tindakan sewenangwenang dari penegak hukum yang dalam hal ini polisi yang menjadi lembaga eksektuif dalam melakukan penyelenggaraan pemerintahan dalam bidang penegakan hukum yang berati bahwa seseorang akan dapat memperoleh sesuatu yang diharapkan dalam keadaan tertentu. Hukum bertugas menciptakan kepastian hukum karena bertujuan untuk menciptakan ketertiban dalam masyarakat. Kepastian hukum merupakan ciri yang tidak dapat dipisahkan dari hukum terutama untuk norma hukum tertulis. Hukum tanpa nilai kepastian hukum akan kehilangan makna karena tidak lagi dapat dijadikan pedoman perilaku bagi semua orang.

Yang dapat disimpulkan Hukum harus dilaksanakan dan ditegakkan karena setiap orang menginginkan dapat ditetapkannya hukum terhadap peristiwa konkrit yang terjadi, bagaimana hukumnya, itu yang harus diberlakukan pada setiap peristiwa yang terjadi. Jadi pada dasarnya tidak ada penyimpangan. Bagaimanapun juga hukum harus ditegakkan, hingga muncul perumpamaan "meskipun besok hari kiamat, hukum harus tetap ditegakkan”. Inilah yang diinginkan oleh setiap orang dengan adanya kepastian hukum agar terciptanya suatu keadilan dalam berkehidupan berkebangsaan.
Hukum ada untuk ditaati, dilaksanakan dan ditegakkan. Dalam kaitannya dengan penegakan hukum, maka pelaksanaan penegakan hukum merupakan fase dari penegakan kedaulatan, atau dengan kata lain penegakan kedaulatan tidak terlepas dari kegiatan penegakan hukum. Karena penegakan hukum merupakan faktor utama dalam mewujudkan dan membina wibawa negara atau pemerintah demi tegaknya kedaulatan negara. Pelaksanaan penegakan hukum dalam masyarakat haruslah memperhatikan beberapa hal, antara lain:

1. Manfaat dan kegunaan bagi masyarakat, karena hukum dibuat untuk kepentingan masyarakat.

2. Mencapai keadilan, artinya dalam penegakan hukum harus mempertimbangkan berbagai fakta dan keadaan secara proporsional.

3. Mengandung nilai-nilai keadilan, yaitu nilai-nilai yang terjabarkan dalam kaidah-kaidah yang mantap dan mengejawantahkan, dan sikap tindak sebagai refleksi nilai tahap akhir untuk menciptakan, memelihara dan mempertahankan keamanan dalam pergaulan hidup.

Kekaburan hukum akibat dari pasal yang multitafsir tersebut dapat dikatakan sebagai bentuk ketidakpastian hukum dari penegakan hukum di Indonesia khususnya di lingkungan kepolisian yang notabene gerbang pertama 
diprosesnya suatu perkara pidana. Dampak dari multitafsirnya pasal tersebut dapat membuat masyarakat menjadi bingung mengenai perbuatan yang boleh dan tidak boleh terkait senjata tajam, selain itu dari aspek penegakan hukum dari pihak kepolisian harus mempertimbangkan berbagai fakta dan keadaan secara proporsional agar terciptanya manfaat dan kegunaan bagi masyarakat.

Berbicara 'Tanpa Hak' disini sebelumnya penulis ingin membahas mengenai Hak, karena hak dan tanpa hak memiliki satu kesatuan yang bertolak belakang, Hak menurut Kamus Besar Bahasa Indonesia adalah sesuatu hal yang benar, milik, kepunyaan, kewenangan, kekuasaan untuk berbuat sesuatu. ${ }^{15}$ Sedangkan menurut Black's Law Dictionary hak adalah:

"As a noun, and taken in an abstract sense, means justice, ethical correctness, or consonance with the rules of law or the priniciples of moral. rights are defined generally as power of free action. And the primal rights pertaining to men are enjoyed by human beings purely as such, being grounded in personality, and existing antecedently to their recognition by positive law. But leaving the abstract moral sphere, and giving to the term a juristic content, a right is well defined as a capacity residing in one man of controling, with the assent and assistance of the state, the actions of others."

Yang apabila di artikan ke Bahasa Indonesia:
"Sebagai kata benda, dan diambil dalam arti abstrak, berarti keadilan, kebenaran etis, atau kesesuaian dengan aturan hukum atau prinsip moral hak-hak didefinisikan secara umum sebagai kekuatan tindakan bebas. Dan hak-hak dasar yang berkaitan dengan laki-laki dinikmati oleh manusia murni seperti itu, didasarkan pada kepribadian, dan ada sebelum pengakuan mereka oleh hukum positif. Tetapi meninggalkan ruang moral abstrak, dan memberikan istilah hukum suatu konten hukum, hak didefinisikan dengan baik sebagai kapasitas yang berada dalam satu orang yang mengendalikan, dengan persetujuan dan bantuan negara, tindakan orang lain.

Apabila dikaitkan dengan hak kepolisian yang telah diberikan melalui Undang-undang Nomor 2 Tahun 2002 Tentang Kepolisian yang menjadi kewenangan kepolisian pasal 15 ayat (1) dan (2) yang berisi:

Ayat (1) dalam rangka menyelengarakan tugas sebagaimana yang dimaksud pasal 13 dan 14 Kepolisian Republik Indonesia secara umum berwenang:

a. menerima laporan dan/atau pengaduan;

b. membantu menyelesaikan perselisihan warga masyarakat yang dapat mengganggu ketertiban umum;

c. mencegah dan menanggulangi tumbuhnya penyakit masyarakat;

d. mengawasi aliran yang dapat menimbulkan perpecahan atau

15 Tim Penyusun Kamus Pusat, (2007), Kamus Besar Bahasa Indonesia Edisi Ketiga, Jakarta: Balai Pustaka, hlm. 427. 
mengancam persatuan dan kesatuan bangsa;

e. mengeluarkan peraturan kepolisian dalam lingkup kewenangan administratif kepolisian;

f. melaksanakan pemeriksaan khusus sebagai bagian dari tindakan kepolisian dalam rangka pencegahan;

g. melakukan tindakan pertama di tempat kejadian;

h. mengambil sidik jari dan identitas lainnya serta memotret seseorang;

i. mencari keterangan dan barang bukti;

j. menyelenggarakan Pusat Informasi Kriminal Nasional;

k. mengeluarkan surat izin dan/atau surat keterangan yang diperlukan dalam rangka pelayanan masyarakat;

1. memberikan bantuan pengamanan dalam sidang dan pelaksanaan putusan pengadilan, kegiatan instansi lain, serta kegiatan masyarakat;

m. menerima dan menyimpan barang temuan untuk sementara waktu.

Dan ayat (2) Kepolisian Negara Republik Indonesia sesuai dengan peraturan perundangan-undangan lainnya berwenang:

a. memberikan izin dan mengawasi kegiatan keramaian umum dan kegiatan masyarakat lainnya;

b. menyelenggarakan registrasi dan identifikasi kendaraan bermotor; c. memberikan surat izin mengemudi kendaraan bermotor;

d. menerima pemberitahuan tentang kegiatan politik;

e. memberikan izin dan melakukan pengawasan senjata api, bahan peledak, dan senjata tajam;

f. memberikan izin operasional dan melakukan pengawasan terhadap badan usaha di bidang jasa pengamanan;

g. memberikan petunjuk, mendidik, dan melatih aparat kepolisian khusus dan petugas pengamanan swakarsa dalam bidang teknis kepolisian;

h. melakukan kerja sama dengan kepolisian negara lain dalam menyidik dan memberantas kejahatan internasional;

i. melakukan pengawasan fungsional kepolisian terhadap orang asing yang berada di wilayah Indonesia dengan koordinasi instansi terkait;

j. mewakili pemerintah Republik Indonesia dalam organisasi kepolisian internasional;

k. melaksanakan kewenangan lain yang termasuk dalam lingkup tugas kepolisian.

Jika dilihat dari hak dan telah menjadi kewenangan polisi pada pasal 15 ayat 2 huruf (e) memberikan izin dan melakukan pengawasan terhadap senjata api, bahan peledak dan senjata tajam. Hak tersebut ada 
karena telah diamanahkan kepada kepolisian melalui Undang-undang, kewenangan tersebut juga menjadi hak bagi polisi untuk melakukan pengawasan terkait senjata api, bahan peledak dan senjata tajam tujuannya untuk menjaga keamanan dan ketertiban masyarakat yang memiliki kondisi dinamis agar terciptanya suatu keadaan terselenggaranya proses pembangunan nasional dalam rangka tercapainya tujuan nasional yang ditandai oleh terjaminnya keamanan, ketertiban, dan tegaknya hukum, serta terbinanya ketenteraman, yang mengandung kemampuan membina serta mengembangkan potensi dan kekuatan masyarakat dalam menangkal, mencegah, dan menanggulangi segala bentuk pelanggaran hukum dan bentuk-bentuk gangguan lainnya yang dapat meresahkan masyarakat.

Sedangkan frasa tanpa hak dalam pasal 2 ayat 1 yang berbunyi:

"Barang siapa yang tanpa hak memasukkan ke Indonesia, membuat, menerima, mencoba memperolehnya, menyerahkan atau mencoba menyerahkan, menguasai, membawa, mempunyai persediaan padanya atau mempunyai dalam miliknya, menyimpan, mengangkut, menyembunyikan, mempergunakan atau mengeluarkan dari Indonesia sesuatu senjata pemukul, senjata penikam, atau senjata penusuk (slag-, steek-, of stootwapen), dihukum dengan hukuman penjara setinggi-tingginya sepuluh tahun.

Setelah melihat dasar hukum UndangUndang Darurat Nomor 12 tahun 1951 Pasal 2 ayat 1 Tentang mengubah "ordonnantietijdelijke bijzondere strafbepalingen" (STBL. 1948 Nomor 17) dan Undang-undang Republik Indonesia dahulu Nomor 8 Tahun 1948 yang mengatur barang siapa yang membawa tanpa hak senjata tajam, senjata pemukul, senjata penikam, atau senjata penusuk dapat diuraikan unsur-unsurnya :

\section{Barang Siapa}

Di dalam setiap rumusan pasalpasal KUHPidana maupun tindak pidana, unsur "barang siapa" merupakan sebuah kata yang penting didalam melihat kesalahan dan pertanggungjawaban pidana. Sebagai sebuah kata "barang siapa" maka memerlukan kajian yang cukup serius dalam asas kesalahan dan pertanggungjawaban pidana dalam upaya pembuktian.

Sebagai contoh pasal 362 KUHP tindak pidana pencurian, adanya katakata "barang siapa". Sedangkan tindak pidana diluar KUHP dikenal istilah "setiap orang" Kedua istilah ini baik "barang siapa" maupun "setiap orang" mempunyai konotasi yang sama didalam melihat kesalahan dan pertanggungjawaban. Artinya langsung 
menunjuk kepada perseorangan seseorang dalam dengan kata lain adalah pertanggungjawaban manusia sebagai person (naturalijk persoon).

Namun dalam upaya pembuktian, unsur "barang siapa/setiap orang" tidak serta merta langsung menunjuk kepada perseorangan (naturalijk persoon). Apabila meninjau pada Kitab Undang-undang Hukum Pidana (KUHPidana) Indonesia yang dianggap sebagai subyek hukum pidana hanyalah orang perseorangan dalam konotasi biologis yang alami (naturlijkee person). Selain itu, KUHPidana juga masih menganut asas "sociates delinquere non potest" dimana badan hukum atau korporasi dianggap tidak dapat melakukan tindak pidana.

\section{- Tanpa Hak}

Dengan melihat rumusan frasa tanpa hak dalam delik ini, tersirat suatu pengertian bahwa tindakan/perbuatan sipelaku/Terdakwa adalah bersifat melawan hukum, walaupun didalam delik ini tidak dirumuskan unsur "bersifat melawan hukum" (dalam hal ini menganut bersifat melawan hukum militer materiil). Namun dari kata-kata "Tanpa hak dalam perumusan delik ini, sudah dipastikan bahwa tindakan seseorang sepanjang menyangkut masalah- masalah senjata tajam, api, amunisi atau bahan peledak harus ada izin dari pejabat yang berwenang untuk itu.

Yang dimaksudkan dengan "Tanpa Hak" berarti pada diri seseorang (si Pelaku/Terdakwa) tidak ada kekuasaan, kewenangan, pemilikan, kepunyaan atas sesuatu (dalam hal ini senjata, munisi atau bahan peledak). Dengan demikian bahwa kekuasaan, kewenangan, pemilikan, kepunyaan itu baru ada pada diri seseorang (si Pelaku/Terdakwa) setelah ada izin (sesuai Undang-undang yang membolehkan untuk itu)

Dapat disimpulkan frasa tanpa hak disini jika orang tersebut melakukan perbuatan "tanpa hak" maka orang tersebut dapat dipidana karena dinilai tidak memiliki kepentingan baik secara pribadi atau menurut menurut undang-undang. Berbeda halnya dengan frasa tanpa hak diubah menjadi yang memiliki hak, "hak" disini jika orang tersebut melakukan perbuatan atas dasar "hak" maka orang tersebut tidak dapat dipidana.

Namun jika dilihat dari definisi senjata dan senjata tajam sendiri dapat dikatakan senjata ialah suatu alat yang digunakan untuk melukai, membunuh, atau menghancurkan suatu benda. Senjata dapat digunakan untuk menyerang maupun untuk mempertahankan diri, dan juga untuk mengancam dan melindungi. Apapun yang dapat digunakan untuk merusak psikologi dan tubuh manusia dapat dikatakan senjata. Selain itu senjata 
juga dapat digunakan oleh seseorang untuk melindungi, mengintimidasi, menyerang orang lain ataupun mempertahankan diri dari ancaman serangan orang lain. Sebagian besar dari alat pemotong dan alat penusuk dapat dipergunakan sebagai senjata dan dapat digolongkan sebagai senjata tajam.

Senjata tajam adalah benda yang boleh diperdagangkan secara bebas oleh masyarakat, namun terkadang pemanfaatannya yang dapat disalahgunakan oleh masyarakat dan dapat menimbulkan potensi bahaya terhadap ketertiban dan keamanan di lingkungan masyarakat. Namun terkait dengan pelarangan maupun pembatasan pengunaan barang-barang yang mempunyai potensi berbahaya di lingkungan masyarakat hanya sebatas untuk pertanian, atau untuk pekerjaan rumah tangga atau untuk kepentingan melakukan dengan syah pekerjaan atau yang nyata-nyatanya mempunyai tujuan sebagai barang pusaka atau barang kuno atau barang ajaib (merkwaardigheid). agar dapat menjamin kepastian hukum dan dapat menjamin rasa keamanan serta menciptakan ketertiban di lingkungan masyarakat. Sedangkan pemanfaatan senjata tajam dalam hal yang negatif antara lain digunakan untuk membunuh, mengintimidasi, menganiaya dan lain-lain.

Senjata tajam memiliki peranan penting terhadap keberlangsungan kehidupan manusia. Sebagaimana telah dijelaskan sebelumnya, senjata tajam memiliki dua dampak yang berbeda selain memiliki dampak positif senjata tajam juga memiliki dampak negatif terhadap kehidupan masyarakat, karena pada dasarnya senjata tajam merupakan alat yang berperan besar dalam hal mempermudah pekerjaan manusia, sehingga keberadaan dan kepemilikannyapun tidak dapat dilarang secara mutlak oleh pemerintah, tetapi dari segi perdagangannya, celah peredaran senjata tajam dapat dipersempit agar tidak terjadi peredaran senjata tajam yang dapat dilakukan secara bebas dan tidak terkendali di dalam lingkungan masyarakat.

Saat ini seringkali terjadi kasus kriminal yang disebabkan oleh penyalahgunaan penggunaan senjata tajam oleh oknum masyarakat yang tidak bertanggung jawab. Tindak kriminal dengan menggunakan senjata tajam belakangan ini semakin memprihatinkan, maraknya kasus pembegalan, perampokan dan bentrokan antar kelompok masyarakat dengan menggunakan senjata tajam terjadi di beberapa daerah di Indonesia. hal itu terjadi karena senjata tajam tersebut diperdagangkan secara bebas dan tanpa harus memiliki izin penjualan maupun izin kepemilikan yang jelas, sehingga kasus terkait penyalahgunaan pemanfaatan senjata tajam masih sering terjadi.

Salah satu cara untuk mengetahui hak seseorang untuk dapat menjual maupun memiliki senjata tajam adalah dengan adanya 
suatu perizinan mengenai kegiatan terkait perdagangan dan peredaran senjata tajam. Apabila tidak demikian maka hal tersebut dapat dikatakan sebagai suatu tindakan ilegal atau melawan hukum. Tetapi pada kenyataannya, perdagangan serta kepemilikan senjata tajam dapat dilakukan secara bebas dan tanpa melalui proses verifikasi. Tidak dapat dipungkiri bahwa senjata tajam memiliki peranan penting terhadap budaya dan keberlangsungan hidup manusia. Sehingga pemerintah Indonesia tidak dapat melarang seluruh perdagangan alat yang berupa senjata tajam di Indonesia, seperti kerajian tangan yang termasuk kebudayaan. Sebagian dari senjata tajam memang didesain sedemikian rupa untuk membantu dalam hal memenuhi kebutuhan hidup manusia dalam kesehariannya. Tetapi saat ini banyak beredar senjata tajam yang didesain untuk menyerang atau melukai orang lain yang dengan sengaja diperdagangkan kepada warga sipil sehingga dapat berpotensi menimbulkan tindakan yang melanggar hukum dan mengancam keselamatan orang lain.

Salah satu faktor yang menjadi sarana peredaran senjata tajam di indonesia adalah perdagangan. Senjata tajam dapat diperoleh melalui kegiatan perdagangan. Perdagangan senjata tajam yang dilakukan tanpa dilandasi oleh kepastian hukum dapat menimbulkan dampak negatif bagi masyarakat dan negara. Peredaran yang meliputi unsur pembuatan, perdagangan, dan kepemilikan senjata tajam di Indonesia haruslah disertai oleh hak dan kepentingan yang sah menurut hukum yang berlaku. Hal ini lah yang menjadi kendala yang dihadapi oleh kepolisian dalam melakukan pengawasan dan pengendalian terhadap senjata tajam di Indonesia dikarenakan belum adanya aturan hukum yang spesifik yang mengatur tentang pengawasan dan pengendalian perdagangan, pembuatan dan kepemilikan senjata tajam.

Namun pengaturan mengenai pengecualian larangan kepemilikan senjata telah diatur dalam Pasal 2 ayat (2) UndangUndang Darurat Nomor 12 Tahun 1951 yang berbunyi:

"Dalam pengertian senjata pemukul, senjata penikam atau senjata penusuk dalam pasal ini, tidak termasuk barang-barang yang nyata-nyata dimaksudkan untuk dipergunakan guna pertanian, atau untuk pekerjaanpekerjaan rumah tangga atau untuk kepentingan melakukan dengan syah pekerjaan atau yang nyata-nyata mempunyai tujuan sebagai barang pusaka atau barang kuno atau barang ajaib (merkwaardigheid)."

Pasal 2 ayat (2) diatas, memberikan pengecualian terhadap larangan kepemilikan senjata yang nyata-nyata mempunyai tujuan bagi penggunaan yang nyata-nyatanya dimaksudkan untuk dipergunakan guna pertanian, atau untuk pekerjaan-pekerjaan rumah tangga atau untuk kepentingan melakukan dengan syah perkerjaan. Hal ini dapat dikatakan sebagai hak karena dalam penggunaanya senjata tajam ini digunakan 
untuk menunjang pekerjaannya seperti bertani atau pekerjaan-pekerjaan rumah tangga lainnya. Dan pengecualian lainnya ialah barang pusaka, barang kuno atau barang ajaib. Sedangkan pengertian barang pusaka sendiri adalah suatu istilah yang digunakan untuk menyebutkan suatu benda yang dianggap sakti atau keramat. Biasanya bendabenda yang dianggap keramat di sini umumnya adalah benda warisan yang secara turun-temurun diwariskan oleh nenek moyangnya, seperti misalnya dalam lingkungan keraton. Setiap suku bangsa yang ada di Indonesia memiliki senjata khas yang berakar dari budaya masing-masing suku dan hampir dari keseluruhan berbentuk senjata tajam. Penjelasan tersebut menggambarkan bahwa barang pusaka adalah bagian dari kebudayaan masyarakat Indonesia yang menyatu dan tidak bisa dilepaskan dari kehidupan masyarakat Indonesia.

Namun kembali lagi menurut penulis yang menjadi permasalahan ialah frasa tanpa hak membuat, menerima, mencoba memperolehnya, menyerahkan atau mencoba menyerahkan, menguasai, membawa, mempunyai persediaan padanya atau mempunyai dalam miliknya, menyimpan, mengangkut, menyembunyikan, mempergunakan atau mengeluarkan dari Indonesia sesuatu senjata pemukul, senjata penikam, atau senjata penusuk (slag-, steek-, of stootwapen), karena pada prinsipnya untuk membuktikan bahwa orang tersebut membawa senjata tajam guna melakukan kegiatan pertanian, atau untuk pekerjaan-pekerjaan rumah tangga atau untuk kepentingan melakukan dengan syah perkerjaan sangat sulit dibuktikan apabila masyarakat membawa senjata tajam atau mempunyai persediaan padanya atau mempunyai dalam miliknya yang untuk pekerjaannya. Jika dicontohkan secara sederhana, jika seorang petani membawa sabit/celurit untuk membersihkan rumput di sawah, maka petani tersebut tidak bisa dikenakan ancaman pidana membawa senjata tajam tanpa hak, karena dalam hal ini senjata tajam tersebut digunakan untuk pertanian dan pekerjaan si petani tersebut.

Hal itu karena perijinan kepemilkan dan perdagangan senjata tajam pada tingkat kepolisian yang memiliki hak untuk melakukan pengawasan juga tidak pernah mengeluarkan ijin yang bersifat tertulis yang berhubungan dengan kepemilikan dan perdagangan senjata tajam di Indonesia. Wewenang Kepolisian hanya sebatas penegakan hukum terkait dengan penyalahgunaan pemanfaatan senjata tajam yang melanggar ketentuan hukum pidana, sehingga tidak menyentuh bidang perijinan perdagangan dan kepemilikan senjata tajam.

Tidak ada satu pun pasal atau penjelasan mengenai makna atau arti dari frasa "tanpa hak", hal itulah yang memberikan suatu kekaburan hukum dan menciptakan ketidakpastian hukum dalam perbuatan terkait senjata tajam. Dan tujuan hukum agar 
memberikan pedoman bagi warga negara dalam menghormati hak dan kewajiban antar masyarakat tidak tercipta karena kekaburan hukum pada frasa tanpa hak dalam kehidupan bermasyarakat dan bernegara.

Sebagai perbadingan kita dapat melihat makna atau arti frasa tanpa hak di filipina dalam aturannya mengenai Cybercrime Prevention Act 2012. Dalam Cybercrime Prevention Act 2012 negara Filipina, diatur beberapa tindak pidana di bidang cyber (cybercrime). Salah satunya yaitu dalam Bagian 4 (a) ayat (1) jo Bagian 8 Cybercrime Prevention Act 2012. Lebih jelasnya adalah sebagai berikut: ${ }^{16}$

\section{Section 4 (a)}

(1) Illegal access - The access to the whole or any part of a computer system without right.

\section{Section 8}

"Any person found guilty of any of punishable act enumerated in section 4(a) and 4(b) of this Act shall be punished with imprisonment of prision mayor or a fine of at least two hundred thousand pesos (PhP200,0.00) up to a maximum amount commensurate to the damage incurred or both"

Yang artinya apabila diterjemahkan ke bahasa Indonesia:

Bagian 4 (a)
(1) Akses ilegal - Akses ke seluruh atau sebagian dari sistem komputer tanpa hak.

\section{Bagian 8}

"Setiap orang yang bersalah atas setiap tindak pidana yang disebutkan dalam bagian 4 (a) dan 4 (b) Undang-undang ini, dipidana dengan pidana penjara prision mayor atau denda paling sedikit dua ratus ribu peso (PhP200,0.00) hingga jumlah maksimum sepadan dengan kerusakan yang terjadi atau keduanya."

Dalam Bagian 4 (a) Cybercrime Prevention Act 2012 Negara Filipina di atas, diatur bahwa tindak pidana akses ilegal harus dilakukan dengan "tanpa hak", agar orang yang melakukan perbuatan tersebut dapat dipidana. Frasa "tanpa hak" tersebut dituliskan dengan kalimat "without right". Frasa "Tanpa hak" yang dimaksud dalam Cybercrime Prevention Act 2012 Negara Filipina tersebut adalah sebagaimana yang diatur dalam Bagian 3 (h) Cybercrime Prevention Act 2012, yaitu:

\section{Section 3 (h)}

"without right refer to either: conduct undertaken without or in excess of authority; or (ii) conduct not covered by established legal defences, excuses, court orders, justifications, or relevant principles under the law".

Yang artinya apabila diterjemahkan ke bahasa Indonesia:

Bagian 3 (h)

16 https://www.icj.org/se-asia-security-law/cybercrime-prevention-act-of-2012-republic-act-no-10175/ diakses pada 14 April 2019, Pukul 22.00 WIB. 
“Tanpa hak mengacu pada: perilaku yang dilakukan tanpa atau melebihi kewenangan; atau (ii) perilaku yang tidak berdasarkan hukum, alasan, perintah pengadilan, pembenaran, atau prinsip-prinsip hukum yang relevan."

Sehingga apabila kita lihat pengaturan makna atau tafsir dari tanpa hak dalam Cybercrime Prevention Act 2012 Negara Filipina mengatur mengenai tindak pidana di bidang cyber (cybercrime) yang harus dilakukan dengan "tanpa hak" dan dalam Cybercrime Prevention Act 2012 Negara Filipina juga diatur pengertian dari frasa "tanpa hak" tersebut. Hal ini berbeda dengan Undang-undang Darurat Nomor 12 tahun 1951 Pasal 2 ayat 1 Tentang mengubah "ordonnantietijdelijke bijzondere strafbepalingen" (STBL. 1948 Nomor 17) dan Undang-undang Republik Indonesia dahulu Nomor 8 Tahun 1948 yang tidak memberikan makna atau arti atas frasa "tanpa hak" yang menciptakan kekaburan dan makna dari frasa tanpa hak yang menyebabkan ketidakpastian hukum, hal ini yang menyebabkan cita-cita negara Indonesia sebagai negara hukum belum terwujud.

\section{KESIMPULAN}

Penafsiran Yuridis Unsur Tanpa Hak Dalam Pasal 2 Undang-Undang Darurat Nomor 12 Tahun 1951 Dalam Perspektif Kepastian Dalam Penyelenggaran Negara Hukum, frasa "tanpa hak" membuat, menerima, mencoba memperolehnya, menyerahkan atau mencoba menyerahkan, menguasai, membawa, mempunyai persediaan padanya atau mempunyai dalam miliknya, menyimpan, mengangkut, menyembunyikan, mempergunakan atau mengeluarkan dari Indonesia sesuatu senjata pemukul, senjata penikam, atau senjata penusuk (slag-, steek-, of stootwapen), memiliki makna multitafsir yang menyebabkan suatu ketidak pastian hukum yang dimana hal ini belum tercapainya tujuan dari negara hukum yang dicita-citakan Indonesia. Berbeda dengan negara Filipina yang telah menjelaskan secara explisit mengenai "Tanpa Hak" agar terciptanya kondisi dimana semua orang memahami arti kata "tanpa hak" secara eksplisit.

\section{DAFTAR PUSTAKA}

\section{Buku}

Arief, Barda Nawawi, (2017), Bunga Rampai Kebijakan Hukum Pidana, Cet. Ke-7, Jakarta; Kencana.

Gautama Sudargo, (1973), Pengertian Negara Hukum, Bandung: Alumni.

Ida Bagus Surya Dharma Jaya, (2015), Hukum Pidana Materil \& Formil: Pengantar Hukum Pidana, Jakarta: USAID-The Asian FoundationKemitraan Partnership.

Kaarlo Tauri, (1988), Critical Legal Positivism, Burlington; Ashgate.

Koentjoro, Diana Halim, (2004), Hukum Administrasi Negara, Bogor; Ghalia.

Kusnadi \& Saragi Bintang, (1985), Ilmu Negara, Jakarta: Perintis Press. 
Kusnanto Anggoro dalam makalah "Keamanan, Pertahanan Negara, Dan Ketertiban Umum”, disampaikan pada Seminar Pembangunan Hukum Nasional VIII Oleh Badan Pembinaan Hukum Nasional, Departemen Kehakiman dan HAM RI, Denpasar Bali Tahun 2003.

Mac Iver, Negara Hukum, (1984), Jakarta: Aksara Baru.

Muladi \& Arief, Barda Nawawi, (2010), Teori-Teori dan Kebijakan Hukum Pidana, Bandung: Alumni.

Nicolo Machiavelly dalam Soehino, (2004), Ilmu Negara, Jakarta: Ilmu Negara Cet. 1.
Sianturi, (1986), Asas-Asas Hukum Pidana dan Penerapannya, Jakarta: Alumni.

Soerjono Soekanto, (2007), Pengantar Penelitian Hukum, Cet. 3, Jakarta: UI Press.

Sulistiyono Adi, 2007, Negara Hukum : Kekuasaan, Konsep dan Paradigma Moral, Cet. 1., Surakarta; LPP \& UPT UNS Press.

Tim Penyusun Kamus Pusat, Kamus Besar Bahasa Indonesia Edisi Ketiga, (2002) Jakarta: Balai Pustaka.

Yamin Muhammad, (1982), Proklamasi dan Konstitusi Republik Indonesia, Bogor; Ghalia. 